\title{
Prediction of the probability of revision hip arthroplasty with replacement of the acetabular component depending on the type of its cement fixation
}

\author{
S.N. Izmalkov' ${ }^{1}$ A.N. Bratiychuk ${ }^{1}$, A.K. Usov ${ }^{2}$, F.Sh. Galeev², S.A. Litvinov ${ }^{2}$ \\ ${ }^{1}$ Samara State Medical University, Samara, Russian Federation \\ ${ }^{2}$ V.D. Seredavin Samara Regional Clinical Hospital, Samara, Russian Federation
}

\begin{abstract}
Introduction One of the most common causes of revision hip arthroplasty is aseptic instability of the primary implant. The acetabular component of the implant is less stable, even if fixed with bone cement. Two merits of cemented replacement are important for practical activity of an orthopaedic surgeon: its need for elderly patients and its low cost. In this regard, it is important to predict aseptic instability of the acetabular component and increase its survival by improving the methods of cemented fixation. Purpose To develop a method of predicting the probability of revision hip arthroplasty with replacement of the acetabular component. Materials and methods We studied 102 patients who underwent total cemented hip arthroplasty. Six clinical and radiological criteria were identified associated with revision after 10 years using a multifactorial pathometric analysis. Results A system was developed that allows integral calculation of the probability of revision hip arthroplasty with replacement of only the acetabulum component. The retrospective analysis confirmed the prognosis in $83.3 \%$ of clinical cases. Conclusion The method proposed for prediction allows for a differentiated approach to cemented fixation of the acetabular component in primary arthroplasty, minimizing the probability of revision in 10 years.
\end{abstract}

Keywords: prognosis, revision arthroplasty, hip joint, acetabular component

\section{INTRODUCTION}

Aseptic instability of a primary implant is one of the most common causes of revision hip arthroplasty [1-5]. The acetabular component is less stable in terms of durability. Its aseptic loosening occurs one and a half to two times more often than of the femoral one [6, 7]. It refers to both cementless and cemented types of fixation, despite the continuous improvement of the technical qualities of implants and methods of their installation in both types of arthroplasty [8-11]. At the same time, cemented arthroplasty is more attractive due to its lower cost and the possibility of early mobilization, which is important for elderly patients [12].

There arises the question of predicting aseptic instability of the acetabular component to take measures to increase its survival by improving cemented fixation [13-15].

Our purpose was to develop a method for predicting the probability of revision hip arthroplasty that includes the replacement of the acetabular component, depending on the cemented fixation type in the initial operation of total cemented arthroplasty.

\section{MATERIAL AND METHODS}

The study is based on clinical and radiological data of 102 patients, treated in the period from 2005 to 2017. All patients underwent primary total cemented hip arthroplasty and gave written voluntary informed consent to participate in the study.

Patients were examined before surgery and twice after it, one year and ten years after the operation. During these time periods, twenty-two clinical and radiological criteria were studied prospectively and retrospectively in all the patients. They characterized pain, function of the lower limb, physical activity of the patient, functional length of the limb, range of motion in the hip joint, radiological picture in the involved hip. A number of criteria and their severity grading were borrowed from the Harris scale system.

A ten-year period after the primary operation was taken as the endpoint of the study, when, according to the literature, aseptic instability of the acetabular component develops most frequently. Therefore, in practical terms, the ten-year follow-up period was the most important for prediction. Thus, those who were operated on in 2007 were examined in 2017, and those who underwent primary replacement in 2006 and 2005

Izmalkov S.N., Bratiychuk A.N., Usov A.K., Galeev F.Sh., Litvinov S.A. Prediction of the probability of revision hip arthroplasty with replacement of the acetabular component depending on the type of its cement fixation. Genij Ortopedii, 2019, vol. 25, no 4, pp. 474-480. DOI 10.18019/1028-4427-2019-25-4-474-480. (In Russian) 
were studied in 2016 and 2015, respectively. So, the operations of primary total cemented hip arthroplasty in 102 patients included in the study were performed only in 2007, 2006 and in 2005.

Primary coxarthrosis was an indication in 54 patients (52.3\%); the indication for surgery was a fracture of the femoral neck in $28(27.4 \%)$ and posttraumatic coxarthrosis in 20 (20.3 \%) patients. There were 44 males. Their average age at the time of the primary operation was $72.3 \pm 2.3$ years. There were 58 females in the average age of $68.1 \pm 2.1$ years.

"Moderate" signs of bone rarefaction were visually detected in preoperative X-rays of the hip joint in all patients, including 28 individuals with femoral neck fractures, that corresponded to grades 5 or 4 of the Singh index. A focused densitometric study was not performed. If the preoperative radiographs revealed a completely obvious enlightenment of bone tissue in the area of surgical intervention, then it was interpreted as "pronounced rarefaction", which corresponded to grades 3 to 1 of the Singh index. During the operation, an orthopedic surgeon often revealed thinned bone rods, coarse spongy bone and its excessive fragility.

They were consulted by endocrinologist with the aim of preventing fractures and those patients were prescribed an individual treatment regimen, including non-medication measures (regular motor activity, wearing protectors). One year after the primary operation, densitometry was performed in 34 patients. According to the T-criterion, the level of bone mineral density in them did not exceed $-2.5 \mathrm{SD}$, which corresponded to osteopenia. At the 10-year follow-up, no fractures due to osteoporosis occurred in those patients.

Initially, metal-on-polyethylene implants were installed in all the patients. The technique of cemented fixation of the acetabular component in the initial stages of the operation was as follows. After opening the hip joint capsule, the acetabulum was treated with cutters. One of the most important tasks that an orthopedic surgeon solved during the operation was to achieve full hemostasis. The bone surface was thoroughly treated with a pulsating aseptic fluid, by pressing with napkins, rubbing and pressurization of the bone cement.

Depending on the subsequent stages of primary arthroplasty, the patients were randomly assigned to three groups. Randomization was performed using the "sealed envelope" method. By signing a written voluntary informed consent, every patient was asked to open one of the three envelopes. Each envelope indicated only one variant of the operation (one of the options for cementing the acetabular component). The first envelope contained the variant with six random blind holes and immediate pressing of bone cement. The second one was an option also with six random blind holes and two-stage pressurization of the bone cement. The third one was a variant with only two blind holes and only in the roof of the acetabulum and two-stage pressurization. The clinical groups were recruited depending which envelope the patient chose, and the intervention adhered to the technology of acetabular component fixation chosen.

The patients of the first group (37 patients) had six blind holes, $6 \mathrm{~mm}$ deep, in a random order in the wall of the acetabulum with a 6-mm drill tip. After that, a single dose of non-solidified cement was placed in the acetabulum, which the surgeon pressed and rubbed with his thumb into the acetabulum wall. An acetabular component which was slightly covered with a thin layer of the cement was introduced into the acetabulum thus prepared at an inclination angle of $45^{\circ}$ and an anteversion angle of $15^{\circ}$. Next, a pronounced pressure was exerted on the acetabular cup which was held in place with a standard positioning device. This was the essence of the technique of immediate bone cement pressurization.

After six similar blind openings had been produced in the patients of the second group (31 patients), bone cement was pressed twice. An unhardened bone cement mass of about half a single dose was introduced into the acetabulum. Using a standard impactor or several gauze napkins, embedded in a rubber medical glove, this cement mass was subjected to a pronounced pressure for two minutes (first moment of pressurization). After that, an implantable cup, previously coated with the remaining half of the cement substance, was installed in the acetabulum. The cup was given the necessary position and only then it was held in this position due to slight pressure with a standard positioning device (second moment of pressurization).

In the third clinical group (34 patients), only two blind openings of the same size and shape were created, but only within the most loaded area of the acetabulum, in its roof [16]. After that, two-stage bone cement pressurization was performed similarly as in the patients of the second group. A schematic presentation of the operation completed is shown in Figure 1. 


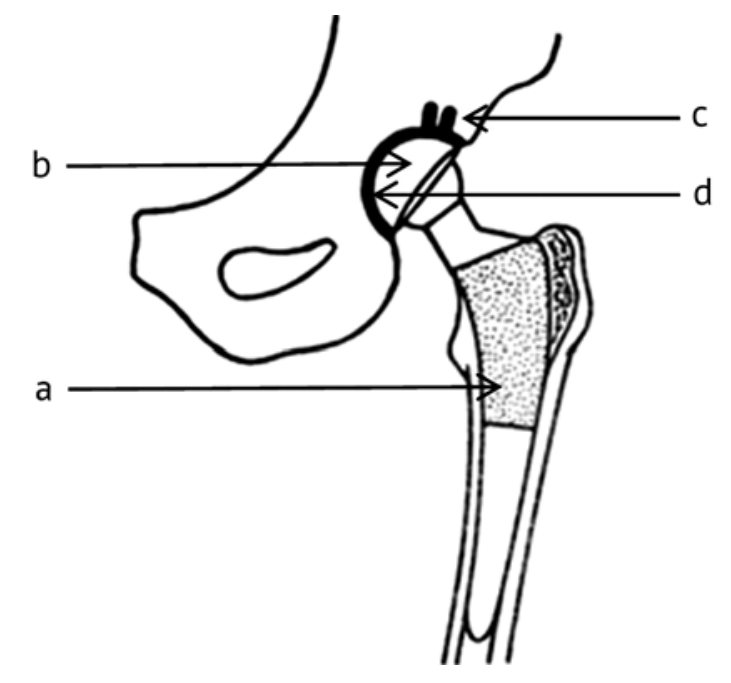

Fig. 1 Completed operation performed in patients of the third clinical group: $a$ femoral component; $b$ acetabular component; $c$ two blind holes in the roof of the acetabulum, filled with bone cement; $d$ cemented mantle formed after two-stage pressurization

Accordingly, three options of cemented fixation of the acetabular component in these three groups were considered [17, 18]. The technique of the femoral component implantation was the same and was based on the principles of the third generation of cemented fixation.

In patients with a "pronounced rarefaction" of bone tissue, bone cement was also used to fix the acetabular component, but blind holes were not produced, and the cement mantle was reinforced with two or more full-threaded screws for spongy bone that were inserted into the most loaded area of the acetabulum, its roof. Such patients were not included in this study. Due to the apparent fragility of their bone tissue, this category of patients was considered an object for a separate specially organized study.

Three clinical groups were recruited only according to the type of fixation while the three nosology types were distributed evenly in the groups.

Bone cement of medium viscosity based on polymethylmethacrylate was used in all the patients. It was mixed in an open bowl. All the arthroscopy procedures were performed by a team of five orthopaedic surgeons of the same hospital department of a multidisciplinary hospital who were experienced in all three types of cemented fixation.
Inclusion criteria were a unilateral hip lesion and acetabular component fixation with medium viscosity bone cement with pre-formed blind holes in the acetabulum wall. The exclusion criteria were cases of visual (during the primary operation) signs of "pronounced rarefaction" of bone tissue and cases of revision surgery with replacement of the femoral component. The study endpoint was 10 years after the initial operation for 59 patients in whom revision was not performed and 43 patients with revision arthroplasties that included replacement of only the acetabular component. The only indication for revision was the aseptic instability of the acetabular component. Nosological types, primary coxarthrosis, secondary coxarthrosis, fracture of the femoral neck, for which primary arthroplasty was performed did not have a statistically significant effect on the revision rate.

Statistical processing used the methods of descriptive statistics and correlation analysis, determining the significance of differences between the groups according to the value of the Student's and Fisher's criteria. A multivariate pathometric analysis was performed, on the basis of which an evaluation system was developed for the dependence of each of the three options for cementing the acetabular component with the facts of revision arthroplasty with replacement of the acetabular component only after 10 years, the maximum term in the development of aseptic instability of the acetabular component [19].

We used the STATGRAPHICS Plus for Windows software package version 4.0 for calculations,. The study was conducted in accordance with the requirements of the Helsinki Declaration of the World Medical Association (as amended in 2013). This work is a randomized, open, comparative, controlled study.

The article was prepared on the basis of the dissertation for the degree of candidate of medical sciences "Improving the fixation strength of the acetabular component in total cemented hip arthroplasty" (author A.K. Usov, supervisor S.N. Izmalkov), defended in 2018.

\section{RESULTS}

The pathometric analysis identified six criteria that have the highest informative value and influence on the probability of both performance and non- performance of revision. Such criteria, with the corresponding values of general information impact (in brackets) were the distance of ambulation (5.8); 
the need for additional means of support (2.4); the ability to sit (2.2); the ability to put on socks and shoes $(1,4)$; severity of pain in the hip $(0.9)$; and the ability to walk up and down the stairs $(0.5)$.

A special computer program (State Registration No. 2017617380 dated 07/04/2017) was developed and the above six criteria were introduced to calculate a comprehensive indicator retrospectively in each of 102 patients. It was named the "integral indicator of revision arthroplasty with replacement of the acetabular component" (abbreviated, II). Final statistical characteristics of the developed evaluation system: $\chi^{2}$ criterion - 90.1 ; sensitivity $-96.7 \%$; specificity - $97.6 \%$; positive diagnostic value $98.3 \%$; negative diagnostic value $-95.4 \%$.

It was established that the higher the II value, the less was probability of revision arthroplasty, regardless of the variant of the primary cemented reinforcement of the acetabular component. On the contrary, the smaller was the II value, the greater was the likelihood of revision intervention. However, in both cases, the likelihood of revision was the least in patients of the third group, which testified to the significant clinical significance of the option to fix the acetabular component applied in them, two-stage pressurization with the preliminary formation of only two blind holes in the roof of the acetabulum.

The II developed was retrospectively calculated in all 102 patients; after that the possibility of determining its prognostic value became obvious by dividing the sample into four prognostic groups: satisfactory, relatively satisfactory, relatively unsatisfactory, and unsatisfactory prognosis. The II values ranged from +26 to -36 conventional units (Fig. 2).



Fig. 2 II values in the sample studied
Based on multivariate pathometric analysis, II values equal to +15 and -15 units were defined as borderline ones. Four prognostic groups were revealed: from +16 and higher were with satisfactory prognosis (28 patients), from 0 to +15 with relatively satisfactory (20 patients), from -1 to -15 - with relatively unsatisfactory (33 patients) and from -16 and lower with an unsatisfactory prognosis (21 patients).

To clarify the statistical reliability of this distinction, we studied the distribution of II values in four prognostic groups and the facts of revision performance or non-performance after 10 years (Table 1).

Satisfactory and relatively satisfactory prognosis was calculated in 48 patients and was retrospectively confirmed in 45 patients, who did not perform the revision operation, and was not confirmed in three patients who underwent the revision.

A relatively unsatisfactory and unsatisfactory prognosis was calculated in 54 patients and was confirmed in 40 patients, who performed the revision; and was not confirmed in 14 patients, in whom, on the contrary, the revision was not performed.

Thus, out of the whole sample, the prognosis was confirmed in 85 patients $(83.3 \%)$, and was not confirmed in 17 patients (16.7\%) (Table 2).

The mathematical models used in biological systems are considered acceptable if they provide a diagnostic accuracy in the range of 70-90\%, and the probability of error in the diagnosis is no more than 10-30\% [20]. Therefore, we believe that the confirmation of the prognosis in $83.3 \%$ of clinical observations can be interpreted as the value of the clinical efficiency of the prognosis (diagnosis) of the revision intervention.

In addition, we examined the relationship between the facts of non-performance and implementation of the revision and groups of patients (Table. 3).

The revision intervention was more frequent in the patients of the first group and the least frequent in the third. Correspondingly, on the contrary, nonperformance was more frequent in the third group and less frequent in the first one. 
Distribution of patients according to prediction type and revision performance

\begin{tabular}{|l|c|c|c|c|}
\hline \multirow{2}{*}{ Prognosis type } & \multicolumn{4}{|c|}{ Revision } \\
\cline { 2 - 5 } & \multicolumn{2}{|c|}{ Non-performed } & $\mathrm{n}$ & $\%$ \\
\cline { 2 - 5 } & $\mathrm{n}$ & 9 & $1^{* *}$ & 3.7 \\
\hline Satisfactory, $\mathrm{n}=28$ & $27^{*}$ & 96.3 & $2^{* *}$ & 10.0 \\
\hline Relatively satisfactory, $\mathrm{n}=20$ & $18^{*}$ & 90.0 & $20^{*}$ & 60.6 \\
\hline Relatively unsatisfactory, $\mathrm{n}=33$ & $13^{* * *}$ & 39.4 & $20^{*}$ & 95.2 \\
\hline Unsatisfactory, $\mathrm{n}=21$ & $1^{* *}$ & 4.8 & 43 & 42.2 \\
\hline Total, $\mathrm{n}=102$ & 59 & 57.8 & \\
\hline
\end{tabular}

Note: $*$ - prognosis confirmed; ** - prognosis unconfirmed

Table 2

Distribution of patients according to revision prognosis, its performance or non-performance

\begin{tabular}{|c|c|c|c|c|c|c|}
\hline \multirow{3}{*}{ Prognosis } & \multicolumn{4}{|c|}{ Revision } & \multirow{2}{*}{\multicolumn{2}{|c|}{ Total }} \\
\hline & \multicolumn{2}{|c|}{ Not performed } & \multicolumn{2}{|c|}{ Performed } & & \\
\hline & $\mathrm{n}$ & $\%$ & $\mathrm{n}$ & $\%$ & $\mathrm{n}$ & $\%$ \\
\hline Confirmed & 45 & 76.3 & 40 & 93.0 & 85 & 83.3 \\
\hline Non-confirmed & 14 & 23.7 & 3 & 7.0 & 17 & 16.7 \\
\hline Total & 59 & 100 & 43 & 100 & 102 & 100 \\
\hline
\end{tabular}

Table 3

Distribution of patients according to revision performance or non-performance in the clinical groups

\begin{tabular}{|c|c|c|c|c|c|c|}
\hline \multirow{3}{*}{ Revision } & \multicolumn{6}{|c|}{ Clinical groups } \\
\hline & \multicolumn{2}{|c|}{$\mathrm{I}$} & \multicolumn{2}{|c|}{ II } & \multicolumn{2}{|c|}{ III } \\
\hline & $\mathrm{n}$ & $\%$ & $\mathrm{n}$ & $\%$ & $\mathrm{n}$ & $\%$ \\
\hline Not performed, $\mathrm{n}=59$ & 8 & 13.6 & 18 & 30.5 & 33 & 55.9 \\
\hline Performed, $\mathrm{n}=43$ & 29 & 67.4 & 13 & 30.2 & 1 & 2.4 \\
\hline Total, $\mathrm{n}=102$ & 37 & 36.3 & 31 & 30.4 & 34 & 33.3 \\
\hline
\end{tabular}

\section{DISCUSSION}

Studies to predict the results of such operations are few. So, N. Arden et al. identified six predictors of revision hip and knee joint replacements at five years after the primary operation: pain severity, grade of impaired limb function, self-service limitations, age, mental status, and radiological width of the joint gap. Moreover, the prognosis was not associated with cemented or cementless arthroplasty. No recommendations were given on tactics in cases of anticipating an adverse outcome [21]. I. Kaymaz et al. emphasize the need for more time duration for calculating the numerical parameters of the prediction [22].

Our study enabled a ten-year perspective to stratify the prediction into four types with the definition of numerical boundaries between them and formulate recommendations on the initial variant of cementing for each prediction type (Table 4).

Computer calculation of the prognosis and decision-making on the tactics of cementing the acetabular component of the hip implant takes up to five minutes.

Table 4

Recommendation on cemented fixation of the acetabular component

\begin{tabular}{|c|l|l|}
\hline II value & \multicolumn{1}{|c|}{ Prognosis type } & \multicolumn{1}{c|}{ Variant of cementing } \\
\hline$(+) 16$ and $>$ & Satisfactory & Any of the three \\
\hline $0-(+) 15$ & Relatively satisfactory & Second or third variant \\
\hline$(-) 1-(-) 15$ & Relatively unsatisfactory & Variant three \\
\hline$(-) 15$ and $<$ & Unsatisfactory & Preferable variant three \\
\hline
\end{tabular}




\section{CONCLUSION}

1. Prediction of hip arthroplasty revision probability with replacement of the acetabular component 10 years after the initial cemented total arthroplasty can be carried out on the basis of six clinical and radiological criteria identified before the primary operation, followed by calculation the II index of the probability using a special computer program.

2. Among the options for cementing the acetabular component, the most optimal that shows the least probability of revision, is the third option, which provides only two blind holes in the roof of the acetabulum and the subsequent two-stage pressurization of bone cement.

3. Clinical efficiency of the proposed differentiated tactics for cementing the acetabular component in hip arthroplasty reaches $83.3 \%$.

4. As the number of cases increases, this method for predicting aseptic instability can also be extended to patients operated on primarily 15 or more years ago.

\section{Conflict of interest The authors declare that there is no conflict of interest. \\ Sources of financing The authors did not receive any funding.}

\section{REFERENCES}

1. Akulich Iu.V., Podgaets R.M., Skriabin V.L., Sotin A.V. Issledovanie vliianiia prostranstvennoi orientatsii atsetabuliarnogo komponenta endoproteza tazobedrennogo sustava na razvitie asepticheskoi nestabilnosti implantata [Studying the influence of spatial orientation of the hip implant acetabular component on developing the implant aseptic instability]. Rossiiskii Zhurnal Biomekhaniki, 2007, vol.11, no. 3, pp. 72-83. (in Russian)

2. Kaminskii A.V., Marchenkova L.O., Pozdniakov A.V. Revizionnoe endoprotezirovanie tazobedrennogo sustava: epidemiologiia, prichiny, factory riska (obzor zarubezhnoi literatury) [Revision arthroplasty of the hip: epidemiology, causes, risk factors (Review of the foreign literature)]. Vestnik Travmatologii i Ortopedii im. N.N. Priorova, 2015, no. 2, pp. 83-89. (in Russian)

3. Kovalenko A.N., Shubniakov I.I., Tikhilov R.M., Chernyi A.Zh. Obespechivaiut li novye i bolee dorogie implantaty luchshii rezultat endoprotezirovaniia tazobedrennogo sustava? [Do new and more expensive implants provide a better result of the hip arthroplasty?]. Travmatologiia i Ortopediia Rossii, 2015, no. 1 (75), pp. 5-20. (in Russian)

4. Tikhilov R.M., Shubniakov I.I., eds. Rukovodstvo po Khirurgii Tazobedrennogo Sustava [Manual for the Hip Surgery]. In 2 Vol. SPb., RNIITO im. R.R. Vredena, 2015, vol.2, 356 p. (in Russian)

5. Corbett K.L., Losina E., Nti A.A., Prokopetz J.J., Katz J.N. Population-based rates of revision of primary total hip arthroplasty: a systematic review. PLoS One, 2010, vol. 5, no. 10, pp. e13520. DOI: 10.1371/journal.pone.00113520.

6. Zagorodnii N.V. Endoprotezirovanie Tazobedrennogo Sustava: osnova i praktika. Rukovodstvo [Arthroplasty of the Hip: basis and practice. A manual]. M., GEOTAR-Media, 2011, 704 p. (in Russian)

7. Tikhilov R.M., Shubniakov I.I., Kovalenko A.N., Totoev Z.A., Bo Liu, Bilyk S.S. Struktura rannikh revizii endoprotezirovaniia tazobedrennogo sustava [Structure of early revisions of the hip arthroplasty]. Travmatologiia i Ortopediia Rossii, 2014, no. 2 (72), pp. 5-13. (in Russian)

8. Kolsanov A.V., Nikolaenko A.N., Ivanov V.V., Prikhodko S.A., Platonov P.V. Obzor materialov i tekhnologicheskikh metodov, primeniaemykh pri izgotovlenii endoprotezov v travmatologii i ortopedii [Overview of materials and technological methods used in manufacturing implants in traumatology and orthopaedics]. Nauka i Innovatsii v Meditsine, 2017, no. 3 (7), pp.13-17. (in Russian)

9. Angadi D.S., Brown S., Crawfurd E.J. Cemented polyethylene and cementless porous-coated acetabular components have similar outcomes at a mean of seven years after total hip replacement: a prospective randomised study. J. Bone Joint Surg. Br., 2012, vol. 94, no. 12, pp. 1604-1610. DOI: 10.1302/0301-620X.94B12.28060.

10.Bjerkholt H., Høvik O., Reikerås O. Direct comparison of polyethylene wear in cemented and uncemented acetabular cups. J. Orthop. Traumatol., 2010, vol. 11, no. 3, pp. 155-158. DOI: 10.1007/s10195-010-0104-0.

11.Kim Y.H., Park J.W., Kim J.S., Kim I.W. Twenty-Five- to Twenty-Seven-Year Results of a Cemented vs a Cementless Stem in the Same Patients Younger Than 50 Years of Age. J. Arthroplasty, 2016, vol. 31, no. 3, pp. 662-667. DOI: 10.1016/j.arth.2015.09.045.

12.Batygin G.G., Redko I.A. Registry po Endoprotezirovaniiu Tazobedrennykh Sustavov [Registers on Arthroplasty of the Hips]. M., Litterra, 2016, 203 p. (in Russian)

13.Zatolokina M.A., Polskoi V.S., Zueva S.V., Laskova A.V., Mezentseva Iu.I., Shekhovtsova A.S., Aseeva S.A., Boeva A.O., Sirdiuk I.V., Sergeeva V.N., Orlova I.A., Pinzhuro O.S. Matematicheskoe modelirovanie i prognozirovanie - kak metody nauchnogo poznaniia $\mathrm{v}$ meditsine i biologii (obzor literatury) [Mathematical modeling and predicting - as methods of scientific cognition in medicine and biology (Review of the literature)]. Mezhdunarodnyi Zhurnal Eksperimentalnogo Obrazovaniia, 2015, no. 12-4, pp. 539-543. (in Russian)

14.Izmalkov S.N., Bratiichuk A.N., Usov A.K., Kuropatkin G.V. Srednesrochnye i otdalennye rezultaty tsementnoi fiksatsii vertluzhnogo komponenta pri totalnom endoprotezirovanii tazobedrennogo sustava [Medium-term and long-term results of cement fixation of acetabular component when total arthroplasty of the hip]. Vestnik Novykh Meditsinskikh Tekhnologii, 2017, vol. 24, no. 2, pp. 88-94. (in Russian)

15.Tarasova I.P. Vozmozhnosti matematicheskogo modelirovaniia i prognozirovaniia v biologii i meditsine [Scopes for mathematical modeling and predicting in biology and medicine]. Vestnik Vitebskogo Gosudarstvennogo Universiteta, 2006, no. 1, pp. $142-145$. (in Russian)

16.Kuropatkin G.V., Akhtiamov I.F. Kostnyi Tsement v Travmatologii i Ortopedii [Bone Cement in Traumatology and Orthopaedics]. Kazan, TaGraf, 2014, 188 p. (in Russian) 
17.Usov A.K. Predvaritelnye rezultaty novoi metodiki tsementirovaniia atsetabuliarnogo komponenta endoproteza tazobedrennogo sustava [Preliminary results of the new technique of cementing the hip implant acetabular component]. Aspirantskii Vestnik Povolzhia, 2014, no. 5-6, pp.119-122. (in Russian)

18.Usov A.K. Sovershenstvovanie ukrepleniya vertluzhnogo komponenta pri total 'nom cementnom e 'ndoprotezirovanii tazobedrennogo sustava. Dis. kand. med. nauk [Improving the strengthening of the acetabular component in total cement hip arthroplasty. Dr. med. sci. diss.]. Samara, 2018. 189 p.

19.Zvereva K.P., Markov D.A., Reshetnikov A.N., Chernov P.A., Bakhteeva N.Kh., Levchenko K.K. Totalnaia revizionnaia artroplastika pri izolirovannoi asepticheskoi nestabilnosti atsetabuliarnogo komponenta [Total hip revision in patients with isolated aseptic loosening of the acetabular component]. Genij Ortopedii, 2018, vol. 24, no. 4, pp. 444-449. (in Russian) DOI: 10.18019/10284427-2018-24-4-444-449.

20.Glantz S.A. Primer of Biostatistics. $4^{\text {th }}$ ed. New York, St. Louis, San Francisco, McGRAW-HILL, 1994, 431 p. (Russ. ed.: Glants S.A. Mediko-biologicheskaia Statistika. Buzikashvili N.E., Samoilov D.V., eds. M., Praktika, 1998, 459 p.)

21.Arden N., Altman D., Beard D., Carr A., Clarke N., Collins G., Cooper C., Culliford D., Delmestri A., Garden S., Griffin T., Javaid K., Judge A., Latham J., Mullee M., Murray D., Ogundimu E., Pinedo-Villanueva R., Price A., Prieto-Alhambra D., Raftery J. Lower limb arthroplasty: can we produce a tool to predict outcome and failure, and is it cost-effective? An epidemiological study. Southampton (UK): NIHR Journals Library; Programme Grants for Applied Research, 2017, vol. 5, no. 12. DOI: 10.3310/ pgfar05120.

22.Kaymaz I., Bayrak O., Karsan O., Celik A., Alsaran A. Failure analysis of the cement mantle in total hip arthroplasty with an efficient probabilistic method. Proc. Inst. Mech. Eng. H, 2014, vol. 228, no. 4, pp. 409-417. DOI: 10.1177/0954411914529428.

Received: 11.03.2019

\section{Information about the authors:}

1. Sergey N. Izmalkov, M.D., Ph.D., Professor, Samara State Medical University, Samara, Russian Federation

2. Alexander N. Bratiychuk, M.D., Ph.D., Professor, Samara State Medical University, Samara, Russian Federation, Email: brat59@bk.ru

3. Alexey K. Usov, M.D., Ph.D., V.D. Seredavin Samara Regional Clinical Hospital, Samara, Russian Federation

4. Farid Sh. Galeev, M.D., V.D. Seredavin Samara Regional Clinical Hospital, Samara, Russian Federation 6. Sergey A. Litvinov, M.D., Ph.D., V.D. Seredavin Samara Regional Clinical Hospital, Samara, Russian Federation 